\title{
PENGARUH PENGEMBANGAN PRODUK USAHA, KERAGAMAN PRODUK EKONOMI KREATIF DAN ETIKA PELAKU USAHA PARIWISATA TERHADAP KEPUTUSAN BERKUNJUNG KE OBJEK WISATA DI KOTA BENGKULU
}

\author{
Veny Puspita, SE., M.M \\ venypuspita2288@gmail.com
}

Fakultas Ekonomi Universitas Prof. Dr. Hazairin, SH Bengkulu

\begin{abstract}
ABSTRAK
Tujuan dilakukannya penelitian ini untuk mengetahui "Pengaruh Pengembangan Produk Usaha, Keragaman Produk Ekonomi Kreatif dan Etika Pelaku usaha Pariwisata terhadap Keputusan Berkunjung ke Objek Wisata di Kota Bengkulu”. Jumlah responden dalam penelitian ini sebanyak 100 orang dengan menggunakan instrument penelitian berupa kuesioner yang hasil datanya dioleh menggunakan instrument SPSS dengan hasil regresi linier berganda $Y=1,196$ $+0,243 X_{1}+0,331 X_{2}+0,412 X_{3}$, perhitungan korelasi berganda sebesar $R=$ 0,736 , berarti pengaruh sama $X_{1}$ (Pengembangan Produk Usaha) $X_{2}$ (Keragaman Produk Ekonomi Kreatif) dan $X_{3}$ (Etika pelaku usaha) terhadap minat berkunjung ke Objek wisata di Kota Bengkulu memiliki hubungan yang kuat karena angka 0,736. Hasil dari uji koofisien determinasi $\left(R^{2}\right)$ sebesar 52,7 \% sedangkan sisanya 47,3\% dipengaruhi oleh variabel-variabel lainnya yang tidak diteliti dalam penelitian ini. Hasil pengujian hipotesis dengan uji $F$, hipotesis yang dibuat membuktikan ada pengaruh. Dimana nilai signifikansi sebesar 0,000 $<0,05$ dan $F_{\text {hitung }}>F_{\text {tabel }}(37,793>2,70)$. Berdasarkan hasil pengujian dengan uji t, hipotesis yang dibuat membuktikan ada pengaruh. Hasil pengujian untuk variabel $X_{l}$ (Pengembangan Produk usaha) menunjukkan thitung lebih besar dari $t_{\text {tabel }}(3,087>1,661)$ dan nilai signifikansi sebesar 0,003 $<0,05$. Variabel $X_{2}$ (Keragaman Produk Ekonomi Kreatif) menunjukkan nilai $t_{\text {hitung }}$ lebih besar dari $t_{\text {tabel }}(3,561>1,661)$ dan signifikansi sebesar 0,001 $<0,05$. Variabel $X_{3}$ (Etika Pelaku usaha) menunjukkan nilai $t_{\text {hitung }}$ lebih besar dari $t_{\text {tabel }}(3,328>1,661)$ dan nilai signifikansi sebesar $0,001<0,05$
\end{abstract}

Kata Kunci : Pengembangan Produk Usaha, Keragaman Produk Ekonomi Kreatif, Etika Pelaku usaha Pariwisata dan Keputusan Berkunjung

\begin{abstract}
The purpose of this research is to find out "The Effect of Business Product Development, Diversity in Creative Economy Products and the Ethics of Tourism Business Actors on the Decision to Visit Tourism Objects in Bengkulu City". The number of respondents in this study were 100 people using a research instrument in the form of a questionnaire whose data were obtained using the SPSS instrument with the results of multiple linear regression $Y=1,196+0,243 X 1+$ $0,331 X 2+0,412 X 3$, the calculation of multiple correlations was $R=0.736$, meaning the same effect X1 (Business Product Development) X2 (Diversity of Creative Economy Products) and X3 (Business Ethics) to the interest of visiting
\end{abstract}


tourist attractions in Bengkulu City has a strong relationship because of the 0.736 figure. The results of the coefficient of determination $\left(R^{2}\right)$ test amounted to $52.7 \%$ while the remaining $47.3 \%$ was influenced by other variables not examined in this study. The results of testing the hypothesis with the F test, the hypothesis is made to prove there is influence. Where the significance value of 0,000<0.05 and Fcount> Ftable (37.793> 2.70). Based on the results of testing with the t test, the hypothesis is made to prove there is an influence. The test results for the X1 variable (Business Product Development) show that tcount is greater than ttable (3.087> 1.661) and the significance value is $0.003<0.05$. Variable X2 (Diversity of Creative Economy Products) shows a tcount greater than ttable (3.561> 1.661) and a significance of $0.001<0.05$. Variable X3 (Business Actor Ethics) shows a tcount greater than ttable (3.328> 1.661) and a value of significance of 0.001 $<0.05$

Keywords: Business Product Development, Diversity of Creative Economy Products, Tourism Business Ethics and Visiting Decisions

\section{PENDAHULUAN}

Dari tahun ketahun jumlah kunjungan wisata ke Indonesia terus meningkat sehingga pariwisata di Indonesia sangat potensial untuk menjadi tumpuan dan harapan pemasukan devisa bagi negara. Pariwisata dapat menjadi mesin penggerak peningkatan devisa di Indonesia. Saat ini pariwisata telah menjadi sebuah industri pariwisata dimana keberadaan industri ini merupakan satu kesatuan yang akan sulit dipisahkan.

Sebagai suatu industri pariwisata menggambarkan banyak bertujuan untuk meyakinkan orang-orang, bahwa pariwisata itu memberikan dampak positif dalam perekonomian, terutama dampak multiplier effect yang ditimbulkan. Industri pariwisata adalah kumpulan usaha pariwisata yang saling terkait dalam rangka menghasilkan barang/ jasa bagi pemenuhan kebutuhan wisatawan dalam penyelenggaraan pariwisata (Undang-undang Pariwisata Nomor 10 Tahun 2009).

Industri Pariwisata merupakan rangkuman dari berbagai bidang usaha yang secara bersama menghasilkan produk dan pelayanan yang nantinya secara langsung akan dibutuhkan oleh wisatawan dalam perjalanan, sehingga dapat disimpulkan bahwa industri pariwisata adalah semua kegiatan usaha baik berupa barang dan jasa yang diperuntukkan untuk para wisatawan. Damarji (Yoeti, 1996)

Pengertian kata industri disini bukanlah suatu tempat untuk mengubah bahan mentah menjadi bahan jadi, namun pengertian kata industri disini lebih cenderung memberikan pengertian industri pariwisata yang artinya kumpulan dari berbagai macam perusahaan yang secara bersama-sama menghasilkan barang dan jasa (goods and service) yang dibutuhkan wisatawan pada khususnya dan travel pada umumnya.

Kebedaraan industri pariwisata tidak terlepas dari Pengembangan Produk Usaha, Keragaman Produk Ekonomi Kreatif dan Etika Pelaku Usaha. Pengembangan produk merupakan komponen bauran pemasaran yang sangat penting karena pengembangan produk dapat menentukan kepuasan dari konsumen. Produk merupakan faktor utama untuk berkompetensi. Manajemen 
produk merupakan salah satu dasar dalam kompentensi jangka panjang dan menyampaikan produk seperti industri pariwisata yang menjadi basis untuk bersaing.

Masalah pengembangan produk usaha merupakan isu yang sangat penting bagi keberadaan industri pariwisata karena inovasi produk dapat dijadikan sebagai salah satu keunggulan bersaing didalam industri pariwisata yang sekarang berkembang sangat kompetitif. Akan ada banyak manfaat yang ditimbulkan dengan berkembangnya industri pariwisata, persaingan antar destinasi pariwisata memaksa Kota Bengkulu untuk menggembangkan sektor ini menjadi sektor unggulan. Ketertarikan konsumen atau wisatawan ditentukan oleh tingkat keyakinan konsumen melihat produk yang ditawarkan dan sejauh mana konsumen merihat produk yang ditawarkan berbeda dengan pilihan alternatif lainnya. Keterkaitan konsumen terhadap suatu perusahaan akan menjadi kuat jika prefrensi konsumen melihat layanan tersebut berbeda dengan yang ada di pasar (Alfansi, 2012).

Manajemen produk yang efektif menjadi salah satu indikator utama dalam berkompetisi untuk jangka panjang karena desain dan penyampaian produk dapat dijadikan sebagai salah satu basis keunggulan bersaing. Kotler mengatakan " $A$ product is anything that can be offered to a market to satisfy a want or need. Product that are marketed in clude physical goods, services, experiences, events, persons, places, properties, organizations, information and ideal" (Kotler, 2000:394)". Produk bukan hanya dikatakan berwujud saja tetapi juga yang tidak berwujud dapat dikatakan produk, semua produk diperuntukkan untuk memberikan kepuasan bagi setiap konsumen. Pengembangan produk pariwisata merupakan tantangan yang besar bagi penyedia jasa pariwisata. Penyedia jasa yang tidak mampu menciptakan produk baru akan meningkatkan risiko penurunan jumlah wisatawan yang akan melakukan kunjungan, hal ini dikarenakan munculnya para pesaing yang lebih kreatif dan inovatif dengan perubahan selera wisatawan serta munculnya teknologi baru dalam setiap proses produksi jasa pariwisata.

Ekonomi kreatif menjadi salah satu isu stratregis yang dapat memanangkan persaingan global dengan terus dilakukannya inovasi dan kreativitas. Ekonomi kreatif merupakan sebuah konsep ekonomi berkembang yang mengintensifkan informasi serta kreatifitas yang mengedepankan pengetahuan, keterampilan ide dan pegetahuan manusia sebagai aset utama penggerak ekonomi.

Keragaman ekonomi kreatif berupa aplikasi, pengembangan permainan, arsitektur, desain interior, desain komunikasi visual, desain produk, fashion, fashion, film animasi, dan video, musik penerbitan, periklanan, seni pertunjukan, seni rupa, televisi dan radio yang mengandalkan keterampilan, talenta dan krativitas berpotensi meningkatkan jumlah kunjungan wisata.

Perubahan variabel lingkungan pemasaran industri pariwiata yang semakin cepat membuat pelaku industri pariwisata harus memperhatikan dampak perubahan tersebut terhadap perilaku wisatawan, perubahan seperti politik, perkembangan ekonomi makro, perubahan ekonomi global, peraturan pemerintah, teknologi informasi, dan perubahan gaya hidup wisatawan. Perubahan ini mengharuskan penyedia jasa industri pariwisata harus mengamati perilaku 
wisatawan jika ingin berkembang dalam industri pariwisata yang semakin kompetitif salah satunya dengan memperhatikan etika palaku usaha

Etika pelaku usaha merupakan hal yang penting yang harus dimiliki guna memasarkan industri pariwisata. Dengan adanya etika usaha penyedia jasa industri pariwisata menjadi lebih bertanggung jawab dan memperhatikan setiap kekurangan yang mereka perbuat sehingga para pelaku industri pariwisata berusaha mengurangi kegagalan atau kesalahan dalam menyediakan jasa.

Berdasarkan latar belakang diatas maka penulis tertarik untuk melakukan penelitian dengan judul "Pengaruh Pengembangan Produk Usaha, Keragaman Produk Ekonomi Kreatif dan Etika Pelaku Usaha Pariwisata terhadap Keputusan Berkunjung ke Kota Bengkulu"

\section{KEPUSTAKAAN}

\section{Manajemen Pemasaran}

Definisi pemasaran menurut Rismiati dan Suratno (2003:3) adalah "suatu proses sosial dan manajerial dengan mana seseorang atau kelompok memperoleh apa yang mereka butuhkan dan inginkan melalui penciptaan dan pertukaran produk serta nilai dengan seseorang atau kelompok lain. Pemasaran adalah suatu proses sosial dan manajerial dimana individu dan kelompok mendapatkan apa yang mereka butuhkan dan inginkan dengan menciptakan dan mempertukarkan produk yang bernilai dengan kelompok lain”. (Kotler, 2005:6).

\section{Pengembangan Produk}

Pengembangan produk ( Product development) adalah suatu kegiatan atau aktifitas yang dilakukan dalam menghadapi kemungkinan prubahan suatu produk kearah yang lebih baik sehingga dapat memberikan daya guna maupun daya pemua yang lebih besar (Assaury; 1996). Menurut Kotler dan Amstrong ( 2008 : 309) "Pengembangan produk merupakan menggembangkan konsep prosuk menjadi produk nyata untuk dapat memastikan bahwa ide produk dapat diubah menjadi produk yang bias dikerjakan". Pengembangan produk merupakan strategi pemasaran yang memerlukan penciptaan produk baru yang dapat di pasarkan, proses merubah aplikasi untuk teknologi baru yang dapat dipasarkan. Indikator pengembangan produk baru meliputi :

1. Produk baru yaitu : (a) produk yang benar-benar inovatif dan unik; (b) produk pengganti yang benar-benar berbeda dan produk yang sudah ada; (c) produk imitative, produk yang barubagi perusahaan tertentu tetapi bukan baru dalam pasar; (d) produk yang menggunakan bahan baku yang baru sama sekali.

2. Pengembangan Produk yaitu : (a) Reset pemasaran; (b) rekayasa; (c) desain.

3. Modifikasi produk, yaitu memperbaiki prosuk yang sudah ada yang memiliki kualitas, fitur, dan style yang bertujuan meningkatkan penjualan. Dimensinya yaitu : (a) perbaikan mutu; (b) perbaikan cirri khas; (c) style improvement.

4. Merchandiding, yaitu semua aktifitas perencanaan baik dari produsen maupun pedagang yang dimaksudkan untuk menyelesaikan antara produk-produk yang dihasilkan dengan permintaan pasar. Adapun yang menjadi tujuan pengembangan produk yaitu memberitahukan kepada para konsumen bahwa 
perusahaan masih memiliki kekuatan persaingan yang begitu penting untuk mempertahankan kesetiaan pelanggan. Secara ideal perusahaan menemukan produk baru untuk mendesak ke luar produk yang lama yang tidak diminati oleh konsumen.

\section{Keragaman Produk Ekonomi Kreatif}

Keragaman produk adalah kumpulan seluruh produk dan barang yang ditawarkan penjual tertentu kepada pembeli ( Kotler,2007) "Industri kreatif adalah industry yang mengandalkan keterampilan, talenta dan kreativitas yang berpotensi meningkatkan kreatifitas dan lapangan pekerjaan". Pengertian keragaman produk menurut James F. Engels "keragaman produk adalah kelengkapan produk yang menyangkut kedalaman, luas dan kualitas produk yang ditawarkan juga ketersediaan produk tersebut setiap saat di toko" (Engels dan Blackwell 1995:258). Dalam industry kreatif bahan baku yang diolah adalah kreatifitas dan pengetahuan manusia itu sendiri seperti periklanan, kuliner, seni, arsitektur, pertunjukan, kerajinan, pasar barang seni, penerbitan dan percetakan, pakaian, pengembangan dan reset, permainan interaktif, music, televise, radio, desain, layanan computer dan piranti lunak serta video, film dan fotografi. (Departemen perdagangan Republik Indonesia)

\section{Etika Pelaku Usaha Pariwisata}

Etika pelaku usaha pariwisata pada dasarnya untuk mengetahui bagaimana para pelaku usaha pariwisata seharusnya bertindak. Etika akan berpengaruh terhadap pelaku bisnis terutama dalam hal kepribadian dan perilakunya. Etika ialah teori tentang perilaku perbuatan manusia, dipandang dari nilai baik dan buruk, sejauh yang dapat ditentukan oleh akal. Tujuan etika bisnis bagi para pelaku usaha adalah untuk mendorong kesadaran moral serta dapat memberikan batasanbatasan bagi para pelaku bisnis untuk menjalankan good business dan tidak melakukan monkey business atau dirty busines. Dengan etika, para pelaku usaha memiliki aturan yang dapat mengarahkan mereka dalam mewujudkan citra dan manajemen bisnis yang baik, sehingga dapat diikuti oleh semua orang yang memercayai bahwa bisnis tersebut memiliki etika yang baik. Etika pelaku usaha dapat menghindari citra buruk seperti penipuan, serta cara kotor dan licik. Bisnis yang memiliki etika baik biasanya tidak akan pernah merugikan bisnis lain, tidak melanggar aturan hukum yang berlaku, tidak membuat suasana yang tidak kondusif pada saingan bisnisnya, dan memiliki izin usaha yang sah.

\section{Keputusan Berkunjung}

Keputusan berkunjung wisatawan merujuk pada konsep keputusan pembelian konsumen yang diadaptasi menjadi keputusan berkunjung wisatawan, seperti penelitian yang dilakukan oleh Jalilvand dan Samiei (dalam Fitri, dkk 2015: 3) yang menyamakan teori keputusan berkunjung wisatawan sama dengan keputusan pembelian konsumen. Menurut Fandy Tjiptono(2008: 21) “ Keputusan pembelian adalah proses dimana konsumen mengenal masalahnya, mencari informasi mengenai produk atau merek tertentu dan mengevaluasi seberapa baik masingmasing alternatif tersebut dapat memecahkan masalahnya, yang kemudian mengarah kepada keputusan pembelian”. Keputusan pembelian adalah tahap di mana pembeli telah menentukan pilihannya dan melakukan pembelian produk, serta mengkonsumsinya (Suharno, 2010: 96). 
Perilaku konsumen merupakan tindakan perorangan dalam memperoleh, menggunakan, serta membuang barang dan jasa, termaksud proses pengambilan keputusan sebelum menetapkan tindakan. Ada lima tingkatan yang dilewati pembeli atau konsumen sebelum mencapai keputusan pembelian yakni pengenalan kebutuhan, pencarian informasi, penilaian pilihan, keputusan pembelian dan perilaku bakda beli. Jelas bahwa proses keputusan wisatawan jika ingin berkunjung ke destinasi pariwisata dimulai jauh sesudah pembelian yang sesungguhnya. Pemasaran harus memberikan perhatian kepada tingkatan proses, dan bukan hanya pada tingkat pembelian keputusan saja (Kotler dan Armstrong, 1997)

\begin{tabular}{|c|c|c|c|c|}
\hline $\begin{array}{l}\text { Pengenal } \\
\text { Kebutuhan }\end{array}$ & $\begin{array}{l}\text { Pencarian } \\
\text { Informasi }\end{array}$ & $\begin{array}{l}\text { Penilaian } \\
\text { Pilihan }\end{array}$ & $\begin{array}{l}\text { Keputusan } \\
\text { Pembelian }\end{array}$ & $\begin{array}{c}\text { Prilaku bakda } \\
\text { Beli }\end{array}$ \\
\hline
\end{tabular}

Gambar 2 Proses Keputusan Pembelian

\section{KERANGKA KONSEPTUAL}

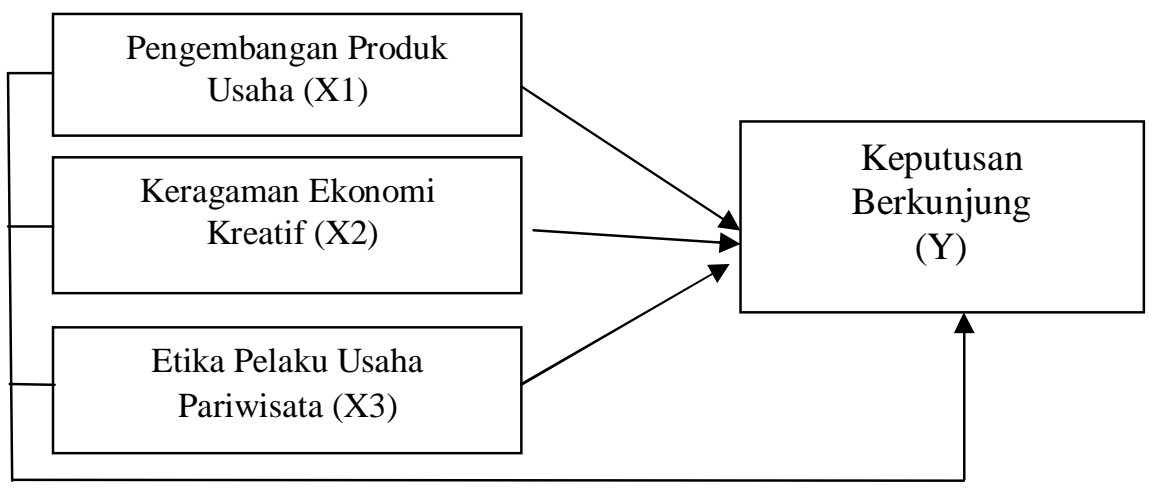

Gambar I Kerangka Penelitian

\section{Hipotesis Penelitian :}

H1 : Pengembangan Produk Usaha, Keragaman Ekonomi Kreatif dan Etika Pelaku Usaha Pariwisata secara simultan berpengaruh terhadap Minat Berkunjung Ke Kota Bengkulu

H2 : Produk usaha berpengaruh terhadap Minat Berkunjung Ke Kota Bengkulu

H3: Keragaman Ekonomi Kreatif berpengaruh terhadap Minat Berkunjung Ke Kota Bengkulu

H4: Etika Pelaku Usaha Pariwisata berpengaruh terhadap Keputusan Berkunjung Ke Kota Bengkulu

\section{METODE PENELITIAN}

Teknik pengambilan sampel yang digunakan dalam penelitian ini dengan menggunakan teknik non probability sampling yaitu teknik sampling yang tidak memberikan kesempatan yang sama bagi setiap unsure atau anggota populasi 
untuk dijadikan sampel. Sampel diambil dengan menggunakan teknik purposive sampling (sampel bertujuan) dengan pemilihan sampel berdasarkan judgement sampling, dimana sampel yang diambil berdasarkan kriteria atau pertimbangan yang ditentukan sendiri oleh peneliti. Responden yang dipilih adalah wisatawan yang berkunjung ke objek wisata di Kota Bengkulu. pengambilan sampel penelitian ini dengan menggunakan rumus :

$$
\mathrm{N}=\frac{\mathrm{Z}^{2}}{4(\mathrm{Moe})^{2}}
$$

Keterangan :

$\mathrm{N}=$ Jumlah sampel

$\mathrm{Z}=$ Tingkat distribusi normal pada taraf signifikan $5 \%=1,96$

Moe $=$ Margin of error $(10 \%)$

Sehingga penelitian ini memperoleh nilai $\mathrm{n}$ sebesar 96,04 dan di bulatkan menjadi 100. Jadi jumlah sampel yang diambil dalam penelitian ini berjumlah 100 orang. Analisis data yang digunakan dalam penelitian ini adalah analisis regresi linier berganda, uji $\mathrm{t}$, uji $\mathrm{f}$ dan koofisien determinasi. Analisis regresi linier berganda digunakan untuk mengetahui hubungan antara variabel independen dengan variabel dependen apakah masing-masing variabel independen berhubungan positif atau negative untuk memperediksi nilai dari variabel dependen apabila nilai variabel independen mengalami kenaikan atau penurunan. Dalam penelitian ini variabel independen adalah Pengembangan Produk Usaha (X1), Keragaman Ekonomi Kreatif (X2) dan Etika Pelaku Usaha Pariwisata (X3) sedangkan variabel dependennya adalah Keputusan berkunjung (Y)

Uji $\mathrm{t}$ digunakan untuk mengetagui seberapa jauh pengaruh variabel bebas (independen) secara individual dalam menjelaskan variasi variabel dependen Dasar pertombangan pengambilan keputusan sebagai berikut : (ghozali, 2001)

1. Dengan membandingkan nilai t hitung dengan $t$ table

a. Jika t table > dari t hitung, maka $\mathrm{H} 0$ di terima dan $\mathrm{H} 1$ ditolak

b. Jika t table < dari t hitung, maka H0 di tolak dan H1 ditolak

2. Dengan menggunakan probabilitas signifikan

a. Apabila nilai signifikannya $>0,05$, maka $\mathrm{H} 0$ diterima dan $\mathrm{H} 1$ ditolak

b. Apabila nilai signifikannya $<0,05$, maka $\mathrm{H} 0$ ditolak dan $\mathrm{H} 1$ diterima

Uji f pada dasarnya bertujuan untuk menunjuknan apakah semua variabel yang dimasukkan dalam model mempunyai pengaruh secara bersama-sama terhadap variabel terikat. Keriteria pengujian dengan membandingkan $F$ hitung dengan $F$ tabel ( Ghozali, 2007) :

a. F hitung < F tabel maka H0 diterima dan Ha di tolak, artinya variabel independen secara bersama-sama tidak mempengaruhi variabel dependen secara signifikan.

b. F hitung > F tabel maka H0 ditolak dan Ha diterima, artinya variabel independen secara bersama-sama mempengaruhi variabel dependen secara signifikan.

Koofisien determinasi $\left(\mathrm{R}^{2}\right)$, pada intinya mengukur seberapa jauh kemampuan model dalam menerangkan variasi variabel terikat. Nilai koofisien determinasi adalah diantara nol dan satu. Nilai yang kecil berarti kemampuan variabelvariabel independen dalam menjelaskan variasi variabel dependen amat terbatas. 
Nilai yang mendekati satu berarti variabel-variabel independen memberikan hampir semua informasi yang dibutuhkan untuk memprediksi variabel-variabel dependen (ghozali, 2007)

\section{HASIL DAN PEMBAHASAN}

\section{Uji Validitas}

Pengujian validitas digunakan untuk mengetahui layak atau tidaknya indikator digunakan dalam penelitian. Hasil pengujian validitas dari indikator penelitian seperti pada tabel berikut :

Tabel I

Uji Validitas Indikator Penelitian

\begin{tabular}{|c|l|c|c|c|}
\hline \multicolumn{1}{|c|}{ No } & \multicolumn{1}{|c|}{ Item Pernyataan } & R-tabel & R-hitung & Keterangan \\
\hline $\begin{array}{c}\text { Pengembangan Produk } \\
\text { usaha (X1) }\end{array}$ & & & \\
\hline 1 & X1.1 & 0,194 & 0,551 & Valid \\
\hline 2 & X1.2 & 0,194 & 0,549 & Valid \\
\hline 3 & X1.3 & 0,194 & 0,617 & Valid \\
\hline 4 & X1.4 & 0,194 & 0,578 & Valid \\
\hline 5 & X1.4 & 0,194 & 0,479 & Valid \\
\hline 6 & X1.6 & 0,194 & 0,616 & Valid \\
\hline 7 & X1.7 & 0,194 & 0,662 & Valid \\
\hline 8 & X1.8 & 0,194 & 0,527 & Valid \\
\hline 9 & X1.9 & 0,194 & 0,534 & Valid \\
\hline 10 & X1.10 & 0,194 & 0,644 & Valid \\
\hline Keragaman Produk Ekonomi & & & \\
Kreatif $($ X2) & & & \\
\hline 1 & X2.1 & 0,194 & 0,280 & Valid \\
\hline 2 & X2.2 & 0,194 & 0,389 & Valid \\
\hline 3 & X2.3 & 0,194 & 0,412 & Valid \\
\hline 4 & X2.4 & 0,194 & 0,491 & Valid \\
\hline 5 & X2.5 & 0,194 & 0,395 & Valid \\
\hline 6 & X2.6 & 0,194 & 0,501 & Valid \\
\hline 7 & X2.7 & 0,194 & 0,535 & Valid \\
\hline 8 & X2.8 & 0,194 & 0,564 & Valid \\
\hline 9 & X2.9 & 0,194 & 0,462 & Valid \\
\hline 10 & X2.10 & 0,194 & 0,400 & Valid \\
\hline Etika Pelaku Usaha (X3) & & & \\
\hline 1 & X3.1 & 0,194 & 0,330 & Valid \\
\hline 2 & X3.2 & 0,194 & 0,341 & Valid \\
\hline 3 & X3.3 & 0,194 & 0,351 & Valid \\
\hline 4 & X3.4 & 0,194 & 0,400 & Valid \\
\hline 5 & X3.4 & 0,194 & 0,376 & Valid \\
\hline 6 & X3.6 & 0,194 & 0,428 & Valid \\
\hline 7 & X3.7 & 0,194 & 0,441 & Valid \\
\hline
\end{tabular}




\begin{tabular}{|c|l|c|c|c|}
8 & X3.8 & 0,194 & 0,457 & Valid \\
\hline 9 & X3.9 & 0,194 & 0,228 & Valid \\
\hline 10 & X3.10 & 0,194 & 0,330 & Valid \\
\hline \multicolumn{2}{|c|}{ Keputrusan Berkunjung (Y) } & & & \\
\hline 1 & Y.1 & 0,194 & 0,326 & Valid \\
\hline 2 & Y.2 & 0,194 & 0,356 & Valid \\
\hline 3 & Y.3 & 0,194 & 0,384 & Valid \\
\hline 4 & Y.4 & 0,194 & 0,608 & Valid \\
\hline 5 & Y.5 & 0,194 & 0,533 & Valid \\
\hline 6 & Y.6 & 0,194 & 0,578 & Valid \\
\hline 7 & Y.7 & 0,194 & 0,523 & Valid \\
\hline 8 & Y.8 & 0,194 & 0,485 & Valid \\
\hline 9 & Y.9 & 0,194 & 0,499 & Valid \\
\hline 10 & Y.10 & 0,194 & 0,303 & Valid \\
\hline
\end{tabular}

Sumber: Hasil oleh data, 2019

Berdasarkan tabel di atas terlihat bahwa tingkat validitas sesuai dengan kriteria yang diajukan pada penelitian ini, yaitu semua pertanyaan memiliki nilai R-hitung > R-tabel. Maka semua variabel yang digunakan dalam penelitian ini valid dan dapat digunakan sebagai alat penelitian.

\section{Uji Reliabilitas}

Pengujian reliabilitas dalam penelitian ini adalah dengan menggunakan rumus Cronbach Alpha. Hasil pengujian reliabilitas adalah sebagai berikut :

Tabel II

Uji Reliabilitas Indikator Penelitian

Cronbach
Variabel Alpha

Keterangan

Pengembangan Produk Usaha (X1)

0,740 Cronbach Alpha $>$ Taraf Signifikan $(0,6)$

Keragaman Produk Ekonomi Kreatif (X2)

0,685 Cronbach Alpha> Taraf Signifikan $(0,6)$

Reliabel

Etika Pelaku usaha (X3)

0,622 Cronbach Alpha> Taraf Signifikan $(0,6)$

Keputusan berkunjung (Y) 0,695 Cronbach Alpha > Taraf Signifikan $(0,6)$

Sumber: Hasil olah data, 2019

Berdasarkan tabel di atas dapat diketahui bahwa nilai Cronbach Alpha lebih besar dari pada taraf signifikan $60 \%(0,6)$, sehingga dapat disimpulkan bahwa instrumen dalam penelitian ini reliabel. 


\section{Analisis Regresi Berganda}

Perhitungan statistik dalam analisis regresi berganda dijelaskan pada tabel berikut ini :

TABEL III

HASIL UJI REGRESI BERGANDA

\begin{tabular}{|c|c|c|c|c|c|c|}
\hline \multicolumn{7}{|c|}{ Coefficients $^{a}$} \\
\hline & \multirow{2}{*}{ Model } & \multicolumn{2}{|c|}{ Unstandardized Coefficients } & $\begin{array}{l}\text { Standardized } \\
\text { Coefficients }\end{array}$ & \multirow{2}{*}{$t$} & \multirow{2}{*}{ Sig. } \\
\hline & & $B$ & Std. Error & Beta & & \\
\hline \multirow[t]{4}{*}{1} & (Constant) & 1.196 & 3.940 & & .304 & .762 \\
\hline & $\begin{array}{l}\text { Pengembangan } \\
\text { Produk Usaha }\end{array}$ & .243 & .079 & .252 & 3.087 & .003 \\
\hline & $\begin{array}{l}\text { Keragaman } \\
\text { Produk Ekonomi } \\
\text { Kreatif }\end{array}$ & .331 & .093 & .329 & 3.561 & .001 \\
\hline & $\begin{array}{l}\text { Etika Pelaku } \\
\text { Usaha }\end{array}$ & .412 & .124 & 303 & 3.328 & .001 \\
\hline
\end{tabular}

a. Dependent Variable: Minat_Berkunjung

Sumber: Hasil olah data, 2019

Dari hasil perhitungan regresi linear berganda dengan menggunakan program SPSS 21.00 maka dapat diperoleh perseamaan regresi linier berganda sebagai berikut :

$$
\begin{aligned}
& \text { Keterangan : } \\
& Y=1,196+0,243 X_{1}+0,331 X_{2}+0,412 X_{3} \\
& \mathrm{Y}=\text { Minat Berkunjung } \\
& \mathrm{X}_{1}=\text { Pengembangan Produk usaha } \\
& \mathrm{X}_{2}=\text { Keragaman Produk Ekonomi Kreatif } \\
& \mathrm{X}_{3}=\text { Etika Pelaku Usaha }
\end{aligned}
$$

Persamaan regresi tersebut dapat dijelaskan sebagai berikut :

1. Nilai konstanta 1,196 mempunyai arti bahwa apabila variabel Pengembangan Produk Usaha $\left(\mathrm{X}_{1}\right)$, Keragaman Ekonomi Kreatif $\left(\mathrm{X}_{2}\right)$ dan Etika Pelaku Usaha $\left(\mathrm{X}_{3}\right)$ dianggap tetap maka variabel Minat berkunjung (Y) akan tetap sebesar 1,196

2. Pengaruh Pengembangan Produk Usaha $\left(\mathrm{X}_{1}\right)$ terhadap Minat berkunjung $(\mathrm{Y})$ Nilai koefesien regresi variabel $\mathrm{X}_{1}$ (Pengembangan Produk Usaha) adalah sebesar 0,243 dengan asumsi apabila $\mathrm{X}_{1}$ (Pengembangan Produk Usaha) mengalami kenaikan sebesar satu-satuan maka Y (Minat berkunjung) juga akan mengalami kenaikan sebesar 0,243 kali.

3. Pengaruh Keragaman Produk Ekonomi Kreatif $\left(X_{2}\right)$ terhadap Minat berkunjung (Y)

Nilai koefesien regresi variabel $\mathrm{X}_{2}$ (Keragaman Produk Ekonomi Kreatif) adalah sebesar 0,331 dengan asumsi apabila $\mathrm{X}_{2}$ (Keragaman Produk Ekonomi Kreatif) mengalami kenaikan sebesar satu-satuan maka Y (Minat berkunjung) juga akan mengalami kenaikan sebesar 0,331 kali.

4. Pengaruh Etika Pelaku Usaha $\left(\mathrm{X}_{3}\right)$ terhadap Minat berkunjung $(\mathrm{Y})$

Nilai koefesien regresi variabel $\mathrm{X}_{3}$ (Etika Pelaku Usaha ) adalah sebesar 
0,412 dengan asumsi apabila $\mathrm{X}_{3}$ (Etika Pelaku usaha ) mengalami kenaikan sebesar satu-satuan maka Y (Minat Berkunjung) juga akan mengalami kenaikan sebesar 0,412 kali.

\section{Korelasi Berganda}

Untuk mengetahui pengaruh pengembangan produk, keragaman produk ekonomi kreatif kreatif dan etika pelaku usaha terhadap minat berkunjung ke objek wisata di Kota Bengkulu, maka dilakukan pengujian korelasi berganda. Adapun hasil perhitungannya sebagai berikut:

Tabel IV

\section{Hasil Uji Korelasi Berganda}

Model Summary

\begin{tabular}{|l|r|r|r|r|}
\hline Model & $\mathrm{R}$ & R Square & \multicolumn{1}{c|}{$\begin{array}{c}\text { Adjusted R } \\
\text { Square }\end{array}$} & $\begin{array}{c}\text { Std. Error of the } \\
\text { Estimate }\end{array}$ \\
\hline 1 & $.736^{\mathrm{a}}$ & .541 & .527 & 2.293 \\
\hline
\end{tabular}

a. Predictors: (Constant), Pengembangan Produk usaha, Keragaman_ produk Ekonomi Kreatif , Etika pelaku usaha

Sumber: Hasil oleh data, 2019

Nilai $\mathrm{R}$ digunakan untuk melihat hubungan antar variabel $\mathrm{X}_{1}$ (Pengembangan Produk Usaha), $\mathrm{X}_{2}$ (Keragaman Ekonomi Kreatif) dan $\mathrm{X}_{3}$ (Pelaku Usaha) terhadap Minat Berkunjung (Y). Semakin besar R berarti hubungan antar variabel semakin erat. Dari hasil output SPSS di atas dapat dilihat nilai $\mathrm{R}=0,736$, berarti pengaruh antara Pengembangan Produk usaha, keragaman produk ekonomi kreatif dan etika pelaku usaha terhadap keputusan berkunjung ke objek wisata di Kota Bengkulu memiliki hubungan yang kuat karena angka 0,736 terletak pada interval $0,60-0,799$.

\section{Koefisien Determinasi $\left(\mathbf{R}^{2}\right)$}

Koefisien determinasi ini digunakan untuk mengetahui seberapa besar pengaruh variabel-variabel bebas memiliki pengaruh terhadap variabel terikatnya. Nilai koefisien determinasi ditentukan dengan nilai adjusted $R$ square.

\section{Tabel IV}

Koefesien Determinasi

Model Summary

\begin{tabular}{|l|r|r|r|r|}
\hline Model & $\mathrm{R}$ & R Square & $\begin{array}{c}\text { Adjusted R } \\
\text { Square }\end{array}$ & $\begin{array}{c}\text { Std. Error of the } \\
\text { Estimate }\end{array}$ \\
\hline 1 & $.736^{\mathrm{a}}$ & .541 & .527 & 2.293 \\
\hline
\end{tabular}

a. Predictors(Constant), Pengembangan Produk usaha, Keragaman_ produk Ekonomi Kreatif , Etika pelaku usaha

Sumber: Olah data, 2019

Untuk nilai koefesien determinasi menggunakan model adjust $R$ square. Dari hasil perhitungan dengan menggunakan SPSS dapat diketahui nilai koefesien determinasi dari adjust $R$ square yaitu sebesar 0,527. Hal ini berarti bahwa $\mathrm{X}_{1}$ (Pengembangan Produk Usaha) $\mathrm{X}_{2}$ (Keragaman Produk Ekonomi Kreatif) dan $\mathrm{X}_{3}$ (Etika pelaku usaha) berpengaruh terhadap minat berkunjung (Y) sebesar 52,7\% 
sedangkan sisanya 47,3\% dipengaruhi oleh variabel-variabel lainnya yang tidak diteliti dalam penelitian ini.

\section{Uji F}

Dalam penelitian ini pengujian hipotesis dimaksudkan untuk mengukur besarnya pengaruh $\mathrm{X}_{1}$ (Pengembangan Produk Usaha) $\mathrm{X}_{2}$ (Keragaman Produk Ekonomi Kreatif) dan $\mathrm{X}_{3}$ (Etika pelaku usaha) terhadap minat berkunjung (Y) maka digunakan uji F. berdasarkan hasil pengujian hipotesis Uji Anova atau uji F terlihat pada tabel berikut.

TABEL IV

HASIL UJI F ANOVA $^{a}$

\begin{tabular}{|ll|r|r|r|r|r|}
\hline Model & & Sum of Squares & df & Mean Square & F & Sig. \\
\hline 1 & Regression & 596.056 & 3 & 198.685 & 37.793 & $.000^{\circ}$ \\
& Residual & 504.694 & 96 & 5.257 & & \\
& Total & 1100.750 & 99 & & & \\
\hline
\end{tabular}

a. Dependent Variable: Minat_Beli

b. Predictors: (Constant), Pengembangan Produk usaha, Keragaman_produk Ekonomi Kreatif , Etika pelaku usaha

Sumber: Penelitian dan diolah, 2017

Berdasarkan Tabel di atas diketahui nilai $\mathrm{F}_{\text {hitung }}$ sebesar 37,793 kemudian dibandingkan dengan nilai $\mathrm{F}_{\text {tabel }}(\mathrm{df} 1=\mathrm{k}-1=4-1=3$, sedangkan $\mathrm{df} 2=\mathrm{n}-\mathrm{k}=100$ 4=96, alpha $=5 \%$ ) adalah sebesar 2,70 , berarti diperoleh $F_{\text {hitung }}>F_{\text {tabel }}(37,793>$ $2,70)$ dengan nilai signifikansi sebesar $0,000<0,05$. Karena tingkat signifikansi di bawah 0,05 menunjukkan bahwa secara bersama-sama $X_{1}$ (Pengembangan Produk Usaha) $\mathrm{X}_{2}$ (Keragaman Produk Ekonomi Kreatif) dan $\mathrm{X}_{3}$ (Etika pelaku usaha) mempunyai pengaruh yang positif dan signifikan terhadap minat berkunjung (Y) keobjek wisata di Kota Bengkulu

Berdasarkan hasil uji simultan maka $\mathrm{H} 0$ ditolak dan Ha diterima, antara Variabel-variabel bebas yaitu $\mathrm{X}_{1}$ (Pengembangan Produk Usaha) $\mathrm{X}_{2}$ (Keragaman Produk Ekonomi Kreatif) dan $\mathrm{X}_{3}$ (Etika pelaku usaha) mempunyai pengaruh yang signifikan secara bersama-sama terhadap Minat berkunjung (Y).

\section{Uji t}

Hasil pengujian hipotesis uji t dengan menggunakan SPSS 21.00 adalah sebagai berikut :

TABEL IV.10

\section{HASIL UJI T}

Coefficientsa

\begin{tabular}{|c|c|c|c|c|c|c|}
\hline & \multirow{2}{*}{ Model } & \multicolumn{2}{|c|}{ Unstandardized Coefficients } & $\begin{array}{l}\text { Standardized } \\
\text { Coefficients }\end{array}$ & \multirow[t]{2}{*}{$\mathrm{t}$} & \multirow[t]{2}{*}{ Sig. } \\
\hline & & $B$ & Std. Error & Beta & & \\
\hline \multirow[t]{4}{*}{1} & (Constant) & 1.196 & 3.940 & & .304 & .762 \\
\hline & $\begin{array}{l}\text { Pengembangan } \\
\text { _Produk }\end{array}$ & .243 & .079 & 252 & 3.087 & .003 \\
\hline & $\begin{array}{l}\text { Keragaman } \\
\text { produk Ekonomi } \\
\text { Kreatif }\end{array}$ & .331 & .093 & .329 & 3.561 & .001 \\
\hline & Etika Pelaku & .412 & .124 & .303 & 3.328 & .001 \\
\hline
\end{tabular}

a. Dependent Variable: Minat_Berkunjung

Sumber: Olah data, 2019 
Dari hasil perhitungan di atas maka dapat dijelaskan sebagai berikut:

1. Variabel $X_{1}$ (Pengembangan Produk)

Hasil pengujian untuk variabel $\mathrm{X}_{1}$ (Pengembangan Produk) menunjukkan $\mathrm{T}_{\text {hitung }}$ sebesar 3,087 kemudian dibandingkan dengan nilai $\mathrm{T}_{\text {tabel }}$ dengan level of signifikan ditetapkan $95 \%$ dengan perhitungan satu arah dan $\mathrm{dk}=\mathrm{n}-4=$ $100-4=94$, diketahui nilai $t_{\text {tabel }}$ sebesar 1,661. Maka $t_{\text {hitung }}$ lebih besar dari $t_{\text {tabel }}$ $(3,087>1,661)$ nilai signifikansi sebesar $0,003<0,05$. Karena nilai $\mathrm{T}_{\text {hitung }}$

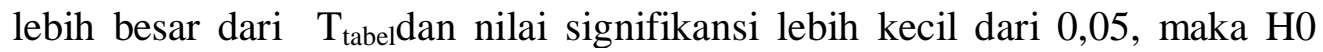
ditolak dan $\mathrm{Ha}$ diterima. Artinya $\mathrm{X}_{1}$ (Pengembangan Produk) memiliki pengaruh yang positif dan signifikan terhadap Minat berkunjung (Y).

2. Variabel $\mathrm{X}_{2}$ (Pengembangan Produk Ekonomi Kreatif)

Hasil pengujian untuk variabel $\mathrm{X}_{2}$ (Pengembangan Produk Ekonomi Kreatif) menunjukkan $\mathrm{T}_{\text {hitung }}$ sebesar 3,561 kemudian dibandingkan dengan nilai $\mathrm{T}_{\text {tabel }}$ dengan level of signifikan ditetapkan 95\% dengan perhitungan satu arah dan $\mathrm{dk}=\mathrm{n}-4=100-4=94$, diketahui nilai $\mathrm{t}_{\text {tabel }}$ sebesar 1,661 . Maka $\mathrm{t}_{\text {hitung }}$ lebih besar dari $t_{\text {tabel }}(3,561>1,661)$ dan nilai signifikansi sebesar $0,001<0,05$. Karena nilai $\mathrm{T}_{\text {hitung }}$ lebih besar dari $\mathrm{T}_{\text {tabel }}$ dan nilai signifikansi lebih kecil dari 0,05, maka H0 ditolak dan Ha diterima. Artinya $\mathrm{X}_{2}$ (Pengembangan Produk) memiliki pengaruh yang positif dan signifikan terhadap Minat berkunjung (Y).

3. Variabel $\mathrm{X}_{3}$ (Etika Pelaku Usaha)

Hasil pengujian untuk variabel $\mathrm{X}_{3}$ (Etika pelaku usaha) menunjukkan $\mathrm{T}_{\text {hitung }}$ sebesar 3,328 kemudian dibandingkan dengan nilai $\mathrm{T}_{\text {tabel }}$ dengan level of signifikan ditetapkan 95\% dengan perhitungan satu arah dan $\mathrm{dk}=\mathrm{n}-4=100$ $4=94$, diketahui nilai $t_{\text {tabel }}$ sebesar 1,661. Maka $t_{\text {hitung }}$ lebih besar dari $t_{\text {tabel }}$ $(3,328>1,661)$ dan nilai signifikansi sebesar $0,001<0,05$. Karena nilai $\mathrm{T}_{\text {hitung }}$ lebih besar dari $\mathrm{T}_{\text {tabel }}$ dan nilai signifikansi lebih kecil dari 0,05, maka $\mathrm{H} 0$ ditolak dan Ha diterima. Artinya $\mathrm{X}_{3}$ (Etika Pelaku Usaha) memiliki pengaruh yang positif dan signifikan terhadap Minat berkunjung (Y).

\section{KESIMPULAN}

Berdasarkan hasil penelitian dan pembahasan yang telah dijabarkan sebelumnya, maka dapat disimpulkan sebagai berikut :

1. Dari perhitungan persamaan regresi linier berganda dapat diketahui bahwa $X_{1}$ sama $X_{1}$ (Pengembangan Produk Usaha) $X_{2}$ (Keragaman Produk Ekonomi Kreatif) dan $\mathrm{X}_{3}$ (Etika pelaku usaha) mempunyai pengaruh terhadap minat berkunjung $(\mathrm{Y})$, dengan hasil uji regresi : $\mathrm{Y}=$ $1,196+0,243 X_{1}+0,331 X_{2}+0,412 X_{3}$

2. Dengan perhitungan korelasi berganda sebesar $\mathrm{R}=0,736$, berarti pengaruh sama $\mathrm{X}_{1}$ (Pengembangan Produk Usaha) $\mathrm{X}_{2}$ (Keragaman Produk Ekonomi Kreatif) dan $\mathrm{X}_{3}$ (Etika pelaku usaha) terhadap minat berkunjung ke Objek wisata di Kota Bengkulu memiliki hubungan yang kuat karena angka 0,736 terletak pada interval 0,60-7,999

3. Nilai koefesien determinasi sebesar 0,527. Hal ini berarti bahwa sama $\mathrm{X}_{1}$ (Pengembangan Produk Usaha) $\mathrm{X}_{2}$ (Keragaman Produk Ekonomi Kreatif) dan $\mathrm{X}_{3}$ (Etika pelaku usaha) berpengaruh terhadap minat berkunjung (Y) sebesar 52,7\% sedangkan sisanya 47,3\% dipengaruhi oleh variabel-variabel lainnya yang tidak diteliti dalam penelitian ini. 
4. Berdasarkan hasil pengujian hipotesis dengan uji $\mathrm{F}$, hipotesis yang dibuat membuktikan ada pengaruh. Dimana nilai signifikansi sebesar 0,000 < 0,05 dan $F_{\text {hitung }}>F_{\text {tabel }}(37,793>2,70)$.

5. Berdasarkan hasil pengujian dengan uji $t$, hipotesis yang dibuat membuktikan ada pengaruh. Hasil pengujian untuk variabel $\mathrm{X}_{1}$ (Pengembangan Produk usaha) menunjukkan $\mathrm{t}_{\text {hitung }}$ lebih besar dari $\mathrm{t}_{\text {tabel }}(3,087>1,661)$ dan nilai signifikansi sebesar $0,003<0,05$. Variabel $\mathrm{X}_{2}$ (Keragaman Produk Ekonomi Kreatif) menunjukkan nilai $\mathrm{t}_{\text {hitung }}$ lebih besar dari $t_{\text {tabel }}(3,561>1,661)$ dan signifikansi sebesar $0,001<$ 0,05.Variabel $\mathrm{X}_{3}$ (Etika Pelaku usaha) menunjukkan nilai $t_{\text {hitung }}$ lebih besar dari $\mathrm{t}_{\text {tabel }}(3,328>1,661)$ dan nilai signifikansi sebesar $0,001<0,05$. Karena nilai $t_{\text {hitung }}$ lebih besar dari $t_{\text {tabeld }}$ dan signifikansi lebih kecil dari 0,05, maka $\mathrm{H} 0$ ditolak dan $\mathrm{Ha}$ diterima. Artinya $\mathrm{X}_{1}$ (Pengembangan Produk Usaha) $\mathrm{X}_{2}$ (Keragaman Ekonomi Kreatif) dan $\mathrm{X}_{3}$ (Etika Pelaku Usaha) memiliki pengaruh yang positif dan signifikan terhadap Minat Berkunjung (Y).

\subsection{Saran}

Berdasarkan kesimpulan dan hasil peneltian ini disarankan kepada Pemerintah dan Pelaku Industri Pariwisata untuk konsen dalam meningkatkan jumlah kunjungan wisata ke Kota Bengkulu dengan cara melakukan Pengembangan Produk Usaha, meningkatkan keragaman ekonomi kreatif dan memberikan pelatihan Etika Pelaku Usaha, karana variabel ini merupakan hal yang sangat pentig di cari oleh para wisatawan.

\section{DAFTAR PUSTAKA}

Assaury Sofyan,Pengembangan Produk, Jilid I, Edisi 196, Yogyakarta 1996

Alfansi, Lizar. 2012. Pemasaran Jasa Finansial. Jakarta: Salemba Empat

Engel, Blackwell, dan Miniard. 1995. Perilaku Konsumen. Jakarta Barat: Binarupa Aksara.

Fitri, dkk. 2015. Pengaruh Word Of Mouth Terhadap Minat Berkunjung Serta Dampaknya Pada Keputusan Berkunjung (Survei pada Pengunjung Tempat Wisata "Jawa Timur Park 2" Kota Batu). Vol. 24 No. 1.

Ghozali, Imam. 2001.Aplikasi Analisis Multivariate Dengan Program SPSS.Semarang: Badan Penerbit Universitas Diponegoro

Kotler, Philip., dan Gary Armstrong., 1997, Dasar-Dasar Pemasaran, Edisi ketujuh, Jilid 1, dialihbahasakan oleh Alexander Sindoro, Jakarta: Prenhallindo

Kotler, Philip. 2000. Marketing Management, Analysis, Planning, Implementation and Control. Edisi IX. New Jersey; Prentice Hall.

Philip Kotler, 2005, ManajemenPemasaran, Jilid I dan II, PT. Indeks, Jakarta

Kotler, Philip, 2007, Manajemen Pemasaran, Jilid 2, Edisi 12, PT Indeks., New Jersey.

Kotler, Philip and Gary Armstrong. 2008. Prinsip-prinsip Pemasaran. Edisi12. Jilid 1. Jakarta: Erlangga

Sunarto, 2003, Prinsip-Prinsip Pemasaran, AMUS, Yogyakarta

Tjiptono, Fandy, 2008, Strategi Pemasaran, Edisi 3, ANDI: Yogyakarta.

Undang-undang Nomor 10 Tahun 2009 tentang Kepariwisataan

Yoeti,A Oka. (1996). Pengantar Ilmu Pariwisata. Angkasa, Bandung. 